\title{
СОЦІАЛЬНИЙ ЗАХИСТ МЕДИЧНИХ ПРАЦІВНИКІВ
}

\section{Соціальний захист медичних працівників}

\section{Т. І. Толокова, О. Ю. Білан}

Тернопільський національний медичний університет імені І. Я. Горбачевського МОЗ України

Резюме. Соціальний захист медичних працівників спрямований на встановлення системи правових і соціальних гарантій, що забезпечує задоволення професійних та матеріальних потреб медиків відповідно до особливого виду їх профресійної діяльності, визначної ролі в суспільстві. Належне регулювання питань фрормування позитивного іміджу медичної профресії, просування ії цінностей надасть профресіоналам у медичній сфрері широкі можливості, які впливають на рівень мотивації та якість надання медичної допомоги пацієнтам.

Мета дослідження - визначити пріоритетні потреби та висхідні запити медиків щодо соціального захисту, а також запропонувати шляхи зміцнення потенціалу підвищення якості медичного обслуговування.

Матеріали і методи. Ми провели анонімне анкетування 100 медичних сестер районної лікарні Комунального некомерційного підприємства Конотопської міської ради «Конотопська чентральна районна лікарня ім. академіка М. Давидова» щодо моральної свідомості пацієнтів, адміністрації лікувального закладу та держави стосовно поваги до медиків, що, у свою чергу, формує вмотивованість у роботі, самооцінку, готовність до альтруїзму в роботі та емпатії в умовах соціального захисту.

Результати. Система управління системою охорони здоров'я України в процесі поглиблення інтеграції в світове економічне співтовариство зазнає багато істотних змін на основі ідеї єднання ефективносmi як результату дієвості соціального компромісу та кваліфрікованої медичної допомоги. Отже, винайдення ефрективних механізмів та дієвих методів фрункціонування системи соціального захисту медичних працівників є нагальним напрямком досліджень та актуальним завданням, що повинно ґрунтуватись на висхідних ініціативах з урахуванням потреб медиків.

Висновки. Якісний соціальний захист дасть змогу висококвалісрікованим медичним працівникам зосередитися на більш важливих завданнях, що передбачають безпосереднє профресійне удосконалення та спілкування з пацієнтом; ключові показники ефрективності медичного персоналу, зокрема щодо якості медичних послуг і задоволення пацієнтів потребують удосконалення й упровадження їх у якості публічної інорормації; необхідно сорормувати кадровий резерв відповідно до кваліфрікаційних запитів й освітніх можливостей, який забезпечу-

\section{Social protection of medical workers}

\section{T. I. Tolokova, O. Y. Bilan}

I. Horbachevsky Ternopil National Medical University

e-mail: tolokova@tdmu.edu.ua

Summary. Social protection of medical workers is aimed at establishing a system of legal and social guarantees that ensure the satisfaction of the professional and material needs of medical workers in accordance with their special type of professional activity and outstanding role in society. Proper regulation of the formation of a positive image of the medical profession, promotion of its values will provide professionals in the medical field with ample opportunities that affect the level of motivation and the quality of medical care for patients.

The aim of the study - to identify the priority needs and bottom-up requests of healthcare providers for social protection, and to propose ways to strengthen the capacity to improve the quality of health care.

Materials and Methods. We conducted an anonymous survey of 100 nurses of the District Hospital of the Communal Non-Profit Enterprise of the Konotop City Council "Konotop Central District Hospital named after Academician M. Davydov" on the moral awareness of patients, the administration of a medical institution and the state in relation to respect for medical workers, which in turn forms motivation in work, self-esteem, readiness for altruism in work and empathy in conditions of social protection.

Results. The management system of the health care system of Ukraine in the process of deepening integration into the world economic community is experiencing many significant changes based on the idea of unity efficiency as a result of the effectiveness of social compromise and qualified medical care. So, the invention of effective mechanisms and effective methods for the functioning of the social protection system of health workers is an urgent direction of research and an urgent task, which should be based on bottom-up initiatives, taking into account the needs of medical professionals.

Conclusions. High-quality social protection will allow highly qualified medical workers to focus on more important tasks that involve direct professional development and communication with the patient; indicators of the effectiveness of medical personnel need to be improved and remain in public information; the formation of a personnel reserve in accordance with qualification requests and educational opportunities will provide a re- 
ватиме ресурс у разі перегляду фуункцій медичних працівників у напрямку новітніх тенденцій дигіталізації й пов'язаних з цим змін у медичному обслуговуванні. Необхідно досліджувати національні можливості для імплементації міжнародних вимог до соціального захисту медиків, з огляду на високі запити сучасної охорони здоров'я щодо якості медичної допомоги.

Ключові слова: соціальний захист; медичний працівник; мотивація працівників.

\section{ВСТУП}

Соціальний захист в Україні реалізується через матеріальне забезпечення економічно активного населення шляхом соціального страхування; пенсійне забезпечення; соціальну допомогу найбільш вразливим категоріям; матеріальну допомогу сім'ям з дітьми; компенсації, індексації та пільги населенню; соціальне обслуговування тощо. Таким чином, соціальний захист здійснюється за допомогою соціального забезпечення та соціальної допомоги [1-3].

Соціальний захист медичних та фрармацевтичних працівників, працівників охорони здоров'я - це функція держави, спрямована на встановлення системи правових і соціальних гарантій, що забезпечує задоволення прооресійних та матеріальних потреб медичних та фрармацевтичних працівників, працівників охорони здоров'я відповідно до особливого виду їх профресійної діяльності, визначної ролі у суспільстві. Державну політику в сорері соціального захисту та соціального забезпечення визначають близько 30 законодавчих актів, серед яких провідне місце належить законам України, указам Президента та постановам Кабінету Міністрів України.

Імперативний вислів, який став крилатим в медицині «Medice, cura te ipsum!», закликає медиків насамперед звернути увагу на самого себе й навчитись, окрім якісної професійної діяльності, фрормуванню поваги з боку пацієнтів, колег, суспільства через навички самоусвідомлення особистої неповторності й важливості [4].

Система управління системою охорони здоров'я України в процесі поглиблення інтеграції в світове економічне співтовариство зазнає багато істотних змін на основі ідеї єднання ефективності як результату дієвості соціального компромісу та кваліфікованої медичної допомоги. Отже, винайдення ефрективних механізмів та дієвих методів функціонування системи соціального захисту медичних працівників $€$ нагальним напрямком досліджень та актуальним завданням, що повинно ґрунтуватись на висхідних ініціативах з урахуванням потреб медиків.

Діюча в Україні система державних соціальних стандартів, пільг, соціальних та компенсаційних source when revising the functions of medical workers in the direction of the latest trends in digitalization and related changes in medical care. It is necessary to investigate the national possibilities for the implementation of international requirements for the social protection of medical workers, given the high demands of modern health care regarding the quality of medical care.

Key words: social protection; health worker; motivation of medical workers.

виплат, соціальних послуг, інших фрорм та видів соціального захисту потребує перегляду та суттєвої модернізації відповідно до Європейської моделі соціального захисту та соціального забезпечення, що ґрунтується перш за все на нормах Європейської соціальної хартії [5].

За результатами експертних оцінок ВОО3, працюючі у бюджетній сорері (а це перш за все медпрацівники), перебувають під впливом багатьох стресових фракторів (в основному негаразди матеріального плану через соціальну незахищеність на місці роботи). Цей оракт не потребує додаткових пояснень щодо його впливу на імунологічний стан та опірність організму, який стає підґрунтям для зростання кількості випадків захворювання серед працівників бюджетної сорери [6].

В Україні не здійснювалася національна оцінка потреб та попиту на медичні кадри, зокрема на лікарів та медичних сестер. Лише в 2019 р. оприлюднені результати звіту підготовленого компанією ТОВ «Делойт енд Туш ЮСК», яка $є$ частиною «Делойт Холдінгз Лімітед» та протягом 175 років здійснює діяльність у сорері управління ризиками, аудиту, консалтингу, за підтримки Агентства США 3 міжнародного розвитку (USAID), наданої від імені народу Сполучених Штатів Америки, за підтримки Програми Уряду Великої Британії «Good Governance Fund», наданої від імені народу Великої Британії у рамках контракту № $72012118 \mathrm{C} 00001$ [7].

Для гармонійного сталого розвитку суспільства та стабільного здоров'я нації необхідна достатня кількість працівників, які кваліфріковано надають медичну допомогу, зокрема лікарів та медсестер.

Мета дослідження - визначити пріоритетні потреби та висхідні запити медиків щодо соціального захисту, а також запропонувати шляхи зміцнення потенціалу підвищення якості медичного обслуговування.

\section{МАТЕРІАЛИ I МЕТОДИ}

Ми розробили й провели анонімне анкетування медичних сестер районної лікарні Комунального некомерційного підприємства Конотопської міської ради «Конотопська центральна районна 
лікарня ім. академіка М. Давидова» щодо моральної свідомості пацієнтів, адміністрації лікувального закладу та держави стосовно поваги до медиків, що, у свою чергу, фрормує вмотивованість у роботі, самооцінку, готовність до альтруїзму в роботі та емпатії в умовах соціального захисту. В дослідження увійшла думка 100 працівників, серед яких 27 медичних сестер мали I та II кваліфікаційну категорії та 46 медиків, які були атестовані як працівники вищої кваліфікаційної категорії. Дані опитування зіставлені з показниками ефективності роботи медичних працівників, отримані зі статистичних даних Центру медичної статистики та Єдиної державної електронної бази відкритих даних в охороні здоров'я, нормативно-правові документи національного рівня та внутрішні керівництва.

\section{РЕЗУЛЬТАТИ Й ОБГОВОРЕННЯ}

Дослідження виконували на базі Конотопської центральної районної лікарні, яка обслуговує 95676 осіб, у тому числі: міського - 66656 чол., сільського - 29020 чол., із них дітей від 0 до 18 років було 13831.

Особливістю щодо умов надання медичної допомоги є те, що місто Конотоп віддалене від обласного центру на 120 км, отже, створюється високий запит до надання всіх видів допомоги й профессіоналізму медиків, а також до можливості взаємовідношень із центрами медичного обслуговування обласного підпорядкування в максимально швидкий й ефективний спосіб. Відстань сільських дільниць від райцентру складає від 6 до 45 км. Найбільша відстань дільниць у місті складає 10-12 км, що також свідчить про специсріку роботи з надання медичної допомоги медсестрами й лікарями поліклініки, яка засновується на високій довірі до ефективного, безпечного лікування пацієнтів.

Ми вивчали самооцінку медичних сестер щодо їх задоволення й захищення, аналізували сприйняття ефективності роботи й навчання, своєї соціальної вартості, престижу профресії та фракторів, які мають вплив на їх усвідомлення.

Основним інструментом оцінки ефективності лікарів та медсестер залишається атестація та частково визначення в нормативно-правових документах, які регулюють систему якості медичної допомоги в Україні [8-11]. За межами атестації оцінка ефрективності персоналу не є системною і швидше $є$ наслідком розслідування певних порушень або помилок, ніж звичною практикою, яка може відобразитись у вигляді заохочень до підвищення якості виконання професійної діяльності, що, у свою чергу, впливає на недостатність мотивації працівників до кваліфікаційного удосконалення (на думку 67 \% респондентів).

У результаті проведено аналізу лише 36 \% опитаних вважають, що думка пацієнтів та колег щодо якості роботи може вплинути на їх впевненість та соціальну захищеність на робочому місці від зловживань та покращить умови їх праці, що підтверджує неформальність такої оцінки та недовіру медиків до неї.

Під час дослідження в загальній кількості середніх медичних працівників ми виділили частки працівників із вищою кваліфікаційною категорією (46 \%), та першою й другою кваліфікаційними категоріями (по 27 \%), що, у свою чергу, зі значною ймовірністю корелює 3 досвідом й стажем трудової діяльності. На основі такого співвідношення ми сорормували кількість (100 анкет) й відповідність результатів анонімного анкетування кваліфікаційних характеристик медиків.

У таблиці представлена інформація щодо кваліфрікаційних характеристик медичних сестер, які працюють в особливих умовах територіальної віддаленості від обласного центру медичної допомоги та географічної широти дільниці обслуговування.

Дані кваліфікаційної відповідності персоналу лікарні свідчать про високу відповідальність та прагнення до профресійного росту медичних сестер лікувального закладу й визначену готовність медичного персоналу до опанування нових компетенцій попри те, що законодавчо гарантовані доплати за підвищення кваліфікаційної категорії недостатні для задоволення життєвих потреб (на думку 82 \% опитаних респондентів).

У закладах охорони здоров'я, які реорганізовано в комунальні некомерційні підприємства у рамках медичної реформи, яким є Конотопська ЦРЛ, частково замість нормативного підходу відповідно до Єдиної тарифної сітки впроваджується договірна система оплати праці персоналу та посилюється роль колективного договору, яким визначаються форми і системи оплати праці, норми праці, розміри фрінансових і несрінансових стимулів.

Медичні працівники недостатньо інформовані про заходи їх соціального захисту на робочому місці, що негативно позначається на рівні їх задо-

Таблиця. Кваліфікаційна категорія середніх медичних працівників

\begin{tabular}{l|c|c|c}
\hline Кваліфікаційна категорія середніх медичних працівників & 2016 р. & 2017 р. & 2018 р. \\
\hline Вища категорія & 201 & 212 & 214 \\
\hline I категорія & 136 & 121 & 118 \\
\hline II категорія & 122 & 143 & 127 \\
\hline Усього середніх медичних працівників & 459 & 476 & 459 \\
\hline
\end{tabular}

ISSN 2706-6282(print) ISSN 2706-6290(online)
Вісник медичних і біологічних досліджень Bulletin of Medical and Biological Research 
волення умовами праці. Питання забезпечення еорективного захисту медичного персоналу від неправомірних або агресивних дій відвідувачів медичних закладів та пацієнтів здебільшого не врегульовано, і медичні працівники не вважають себе захищеними на робочому місці під час виконання профресійних обов'язків. 67 респондентів вказали, що у своїй роботі стикались 3 конфліктною й відверто провокаційною поведінкою пацієнтів або їх родичів, що порушує їх права, й не були обізнані щодо алгоритму захисту себе на робочому місці та поза його межами у таких випадках. Серед опитаних 55,2 \% респондентів мали стаж роботи до 10 років та належали до II або I кваліфікаційної категорії та за даними самооцінки у певних ситуаціях порушення власних прав не мали усвідомлення про фракт порушення їх прав на робочому місці, що доводить недостатню поінформованість на освітньому рівні адмністрацією та галузевим керівництвом.

На рисунку 1 представлені результати анкетування медсестер щодо розуміння захищення їх у професійній діяльності.

Найвища частина визнання у своєму профресійному досвіді випадків порушення прав, що корелює з терміном роботи за спеціальністю у медсестер 3 вищою кваліфікаційною категорією (45 \%). Але 31 \% 3 них вважають себе найменш соціально захищеними у подібних ситуаціях, на відміну від $62 \%$ медичних сестер, які мають стаж роботи до 7 років й 2 кваліфікаційну категорію. Це ймовірно засвідчує формування кредиту довіри молоді в медицині до керівництва системою охорони здоров'я на місцевому та державному рівнях. Медсестри I кваліфрікаційної категорії та стажем роботи до 10 років у $48 \%$ впевнені в своїх знаннях щодо правильного реагування на ситуації 3 можливим порушенням їх прав, своїх комунікативних навичках, але лише у $28 \%$ вважають достатнім соціальний захист медиків. Такий розподіл респондентів може бути пов'язаний зі стажем роботи, специфікою професійної діяльності, рівнем емпатії, емоційного інтелекту та професійного вигорання й потребує пошуку взаємозв'язків на місцевому та галузевому рівні для розв'язування проблем з оптимізації охорони здоров'я [12].
Для якісного розуміння безпечності професійної діяльності розроблений алгоритм звернення медичних працівників у випадку порушення прав під час роботи (рис. 2).

Практична реалізація дотримання такого алгоритму має місце тільки у випадку належного регулювання роботи кожної ланки на шляху розгляду та справедливого реагування на звернення.

В Україні не проводилась національна оцінка потреб та попиту на медичні кадри, зокрема на лікарів та медичних сестер. Лише в 2019 р. оприлюднені результати звіту підготовленого компанією ТОВ «Делойт енд Туш ЮСК», яка є частиною «Делойт Холдінгз Лімітед» та протягом 175 років здійснює діяльність у сорері управління ризиками, аудиту, консалтингу, за підтримки Агентства США 3 міжнародного розвитку (USAID), наданої від імені народу Сполучених Штатів Америки, за підтримки Програми Уряду Великої Британії «Good Governance Fund», наданої від імені народу Великої Британії у рамках контракту № $72012118 \mathrm{C00001}$ [7].

Згідно з даними звіту, співвідношення кількості медичних сестер до лікарів в Україні має тенденцію до зниження, зокрема через негативні темпи приросту кількості медичних сестер, і є нижчим за середньоєвропейський показник. У Конотопській центральній районній лікарні: забезпечення лікарями на 10 тис. населення - 23, середніми медичними працівниками на 10 тис. населення - 76, що підтверджує кадрову кризу в сорері медичної допомоги, яка, у свою чергу, підсилює складність умов праці медиків та високий рівень відповідальності при виконанні професійних обов'язків. Проблема неукомплектованості посад часто вирішується внутрішнім сумісництвом, яке неминуче покладають додаткові об'єми роботи на працівників. На думку 82 респондентів справедливе фрінансове заохочення компенсує перевантаження на робочому місці та доповнює відчуття задоволення від реалізації своїх профресійних здібностей через еорективну медичну допомогу пацієнтам [14].

Наявна вітчизняна система стимулів та мотиваторів у закладах охорони здоров'я, яка включає такі практики:

- прямі фрінансові стимули:

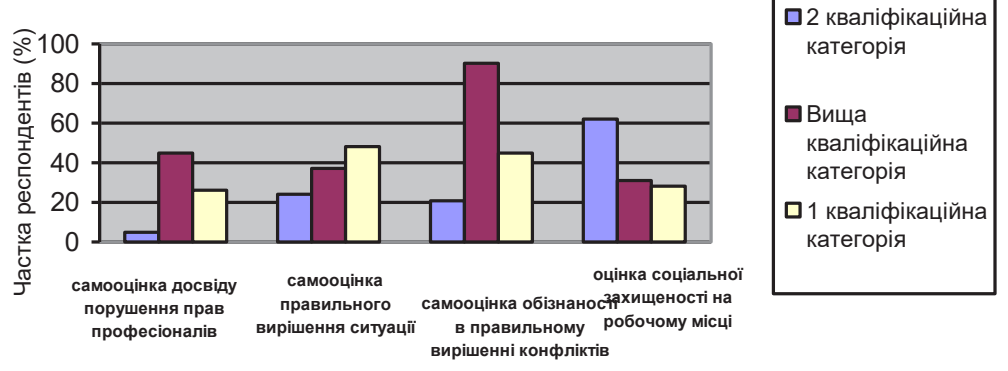

Рис. 1. Інформативність медиків щодо порушень правил. 


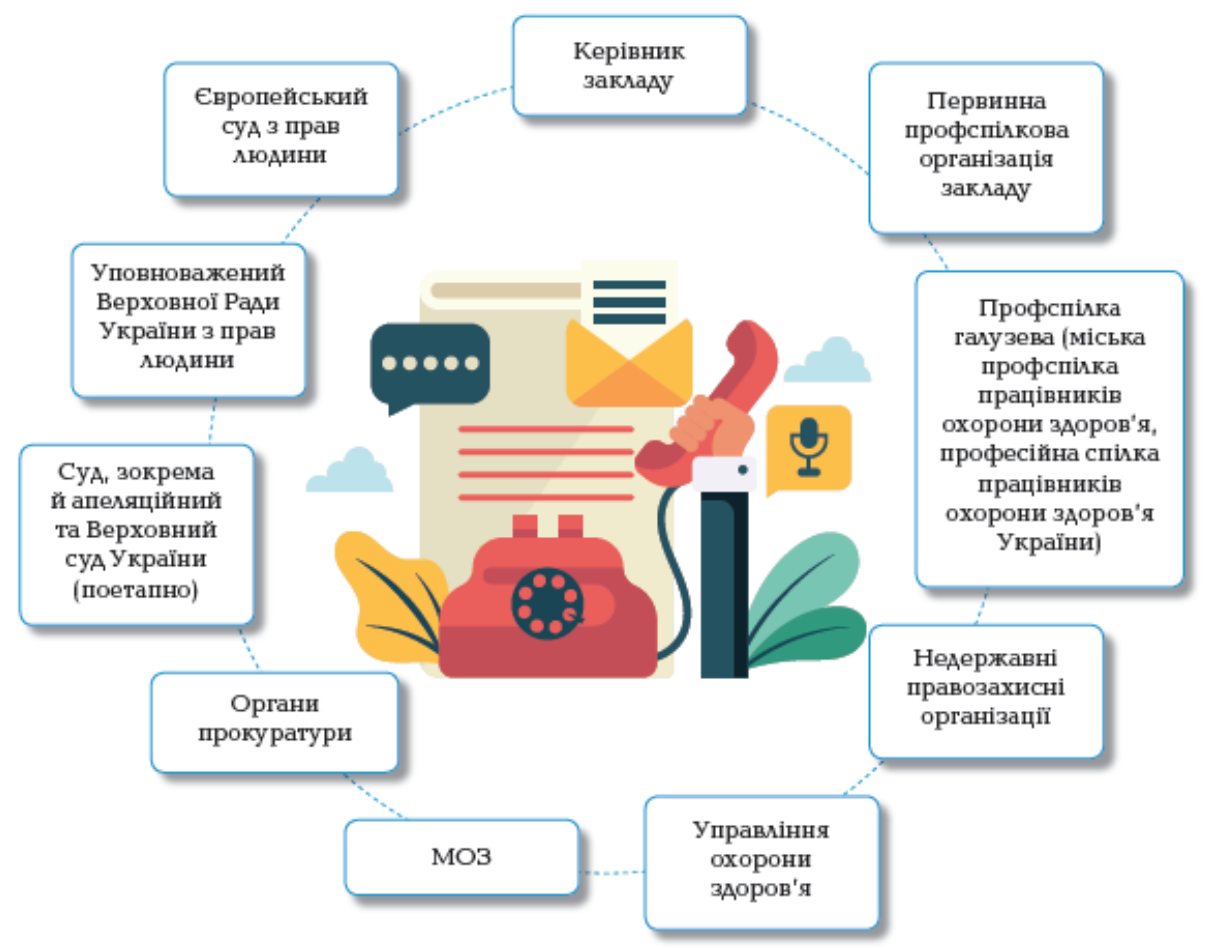

Рис. 2. Алгоритм звернення при порушенні прав медиків на робочому місці.

a) обов'язкові компенсаційні та стимулюючі надбавки і доплати (за особливі умови праці, кваліфікаційну категорію тощо);

б) прямі фрінансові стимули за роботу в сільській місцевості;

в) стимулювання на основі критеріїв профресійної ефективності (в комунальних некомерційних підприємствах та приватних лікувальних закладах);

г) стимулювання за наявність додаткових компетенцій (у приватних закладах охорони здоров'я);

- непрямі фрінансові стимули:

а) оплата навчання, участі у профресійних заходах;

б) переваги та пільги в галузі житлово-побутового обслуговування (здебільшого для медичних працівників у сільській місцевості);

в) вручення подарунків до ювілеїв, державних або професійних свят;

г) непрямі фрінансові стимули за ініціативність та лідерство (у приватних закладах охорони здоров'я);

- нефрінансові стимули:

а) гарантія зайнятості;

б) забезпечення задовільних умов праці;

в) визнання цінності роботи;

г) надання можливості для розвитку та удосконалення.

Серед опитаних медичних працівників усі гарантовано отримують визначені законодавством прямі фрінансові стимули щодо надбавок за роботу в сільській місцевості, особливі умови праці та ква- лісрікаційну категорію. 45 \% опитаних вказують на стимулювання за додаткову компетенцію, а саме здобуті додатково навички, які підтверджені сертифікатами й дипломами та використовуються у профресійній діяльності, що можливо до здійснення згідно з реструктуризацією в комунальне некомерційне підприємство, оскільки такі заклади фрінансуються також поза межами кошторисних призначень статті оплати праці та нарахувань. Участь у просресійних заходах, що спрямована на підвищення профресійної майстерності, на думку 76 опитаних активно заохочується адміністрацією, що проявляється в організації навчальних семінарів та лекцій із попереднім плануванням актуальної тематики в контексті необхідності поглиблення обізнаності у певній низці питань. Серед опитаних тільки 36 \% використовують пільги в галузі житлово-побутового обслуговування, всі ці медичні сестри працюють у сільській місцевості.

За даними анкетування всі медсестри працюють із розумінням поняття емпатії та альтруїзму, що свідчить про достатній освітній рівень в цих визначеннях. Проте необхідно зауважити, за даними національних соціологічних досліджень (КМІС, соціологічна група «Рейтинг»), у 2019 р. вперше за останні п'ять років зростає рівень задоволення пацієнтів державними медичними послугами. Кожен п'ятий українець вважає, що якість державних медичних послуг в Україні упродовж останніх двох років покращилася, раніше таку думку висловлював кожен десятий [15]. 
Медичні сестри здобувають освіту рівня молодшого спеціаліста в медичних училищах та коледжах і далі не продовжують навчання. Наразі вища освіта (рівні бакалавра і магістра) не є офріційною вимогою для працевлаштування на посаду медичної сестри. Водночас в Україні поширюються програми підготовки медичних сестер рівня повної вищої освіти, бакалавра і магістра [16]. 5 \% від загальної кількості респондентів у нашому дослідженні реалізували виявлене бажання продовжувати навчання до вищого рівня освіти.

Стратегічне планування перспектив розвитку медичного закладу із залученням медичних сестер та лікарів використовується рідко, 17 \% медсестер вищої кваліфікаційної категорії вказують на обізнаність у питаннях розвитку закладу. Загальне бачення розвитку закладу в довгостроковій або середньостроковій перспективі у співробітників структурних підрозділів практично відсутнє, що не сприяє мотивації медиків до сприйняття роботи в медицині як стабільного й надійного заняття на тривалий час із гарантованим благополуччям у суспільстві. В результаті проведеного анкетування 82 респонденти не могли ствердно відповісти щодо обізнаності у питаннях перспективи розвитку лікувального закладу, що обґрунтовано урахуванням ступеня їх причетності до реалізації.

Медичний персонал визнає недостатнім рівень можливостей для медичної допомоги та лише частковою прозорістю щодо якості, безпеки послуг й ціни, очікують на впровадження узгоджених, зручних, індивідуальних і доступних рішень у сорері охорони здоров'я. 3 огляду на те, що послуги охорони здоров'я набувають ознак повноцінного «товару», а видатки пацієнтів у межах моделі розподілу витрат збільшуються, підвищення

\section{СПИСОК ЛІТЕРАТУРИ}

1. Про страхування. 85/96-BP https://zakon.rada.gov. ua/laws/show/85/96-\%D0\%B2\%D1\%80\# : Закон України.

2. Про загальнообов'язкове державне соціальне страхування на випадок безробіття. 1533-III https:// zakon.rada.gov.ua/laws/show/1533-14\# : Закон України.

3. Про загальнообов'язкове державне соціальне страхування від нещасного випадку на виробництві та професійного захворювання, які спричинили втрату працездатності. 1105-XIV https://zakon.rada.gov.ua/laws/ show/1105-14\# : Закон України.

4. Вежновець Т. А. Дослідження задоволеності працею та синдром вигорання у медичних працівників / T. А. Вежновець // Scientific Journal ScienceRise: Medical Science. - № 0(2(10)). - C. 36-40. DOI: 10.15587/25194798.2017.94354

5. Європейська соціальна хартія (переглянута) 994_062 https://zakon.rada.gov.ua/laws/show/994_300\#Text

6. Горбатюк І. М. Проблеми соціального захисту медичних працівників протитуберкульозних закладів / І. М. Горбатюк // Український пульмонологічний жур- якості лікування та обслуговування $€$ потенційною ссрерою для кардинальних змін, що безпосередньо пов'язано з якісною мотивацією та соціальним захистом працівників сорери охорони здоров'я як джерела престижу просресії медика й допоможуть приймати зважені й обґрунтовані рішення.

\section{ВИСНОВКИ}

1. Якісний соціальний захист дасть змогу висококваліфрікованим медичним працівникам зосередитися на більш важливих завданнях, що передбачають безпосереднє профресійне удосконалення та спілкування з пацієнтом.

2. Виникла необхідність у розробці ключових показників ефективності медичного персоналу, зокрема щодо якості медичних послуг і задоволення пацієнтів та запровадити їх у якості публічної інорормації.

3. Лідерам галузі охорони здоров'я потрібно сфрормувати кадровий резерв відповідно до кваліфрікаційних запитів й освітніх можливостей, який забезпечуватиме ресурс у разі перегляду функцій медичних працівників у напрямку новітніх тенденцій дигіталізації й пов'язаних з цим змін у медичному обслуговуванні.

4. Міжнародні вимоги щодо соціального захисту медичних працівників, враховуючи високі запити сучасної охорони здоров'я до якості медичної допомоги, потенційно будуть зростати й відповідно до цього необхідно досліджувати національні можливості для імплементації їх у вітчизняну медицину.

5. Необхідно досліджувати національні можливості для імплементації міжнародних вимог до соціального захисту медиків з огляду на високі запити сучасної охорони здоров'я щодо якості медичної допомоги.

нал. - 2008. - № 3. - С. 24-25 http://www.ifp.kiev.ua/doc/ journals/upj/08_dop/8.pdf

7. Кадрові ресурси системи охорони здоров'я в Україні. Ситуаційний аналіз / [Д. Богдан, А. Бойко, А. Васильковата ін.] // Проект USAID «Підтримка реформи охорони здоров'я». - К., 2019 https://www.skeptic.in.ua/ wp-content/uploads/HRH-situational-analysis-2019.pdf

8. Про затвердження Концепції управління якістю медичної допомоги у галузі охорони здоров'я в Україні на період до 2020 року. https://zakon.rada.gov.ua/rada/show/ v0454282-11 : Наказ МО3 України від 01.08.2011 № 454.

9. Про порядок контролю якості медичної допомоги. https://zakon.rada.gov.ua/laws/show/z1996-12 : Наказ МО3 України від 28.09.2012 № 752.

10. Про організацію клініко-експертної оцінки якості медичної допомоги. https://zakon.rada.gov.ua/laws/show/ z0285-16 : Наказ МОЗ України від 06.08.2013 № 693.

11. Про моніторинг клінічних індикаторів якості медичної допомоги. https://zakon.rada.gov.ua/laws/show/ z1669-13 : Наказ МО3 України від 11.09.2013 № 795. 
12. Interventions to prevent and reduce physician burnout: a systematic review and meta-analysis / C. P. West, L. N. Dyrbye, P. J. Erwin, T. D. Shanafelt // The Lancet. - 2016. - Vol. 388, Issue 10057. - P. 2272-2281. DOI: 10.1016/s0140-6736(16)31279-х

13. Електронний журнал «Управління закладом охорони здоров'я» https://egolovlikar.mcfr.ua/

14. Щербакова І. М. Задоволеність профресійною діяльністю як індикатор нейротизму суб'єктів праці /

\section{REFERENCES}

1. Law of Ukraine "On Insurance". Available from: https:// zakon.rada.gov.ua/laws/show/85/96-0D0\%B2\%D1\%80\#Text. Ukrainian.

2. Law of Ukraine "On Compulsory State Social Insurance in Case of Unemployment". Available from: https:// zakon.rada.gov.ua/laws/show/1533-14\#Text. Ukrainian.

3. Law of Ukraine "On Compulsory State Social Insurance against Accidents at Work and Occupational Diseases That Caused Disability". Available from: https:// zakon.rada.gov.ua/laws/show/1105-14\#Text. Ukrainian.

4. Vezhnovecz TA. [Research job satisfaction and burnout syndrome in medical workers] Scientific Journal ScienceRise: Medical Science. 2(10): 36-40. DOI: 10.15587/2519-4798.2017.94354. Ukrainian.

5. European Social Charter (revised). Available from: https://zakon.rada.gov.ua/laws/show/994_300\#Text. Ukrainian.

6. Gorbatyuk IM. [Problems of social protection of medical workers of anti-tuberculosis institutions]. Ukrayinskyi pulmonolohichnyi zhurnal. 2008;3: 24-25. Available from: http://www.ifp.kiev.ua/doc/journals/upj/08_ dop/8.pdf. Ukrainian.

7. Bogdan D, Boyko A, Vasylkovata A. Human resources of the health care system in Ukraine. Situational analysis. USAID Health Care Reform Support Project. Kyiv; 2019. Available from: https://www.skeptic.in.ua/wp-content/ uploads/HRH-situational-analysis-2019.pdf Ukrainian.

8. Order of the Ministry of Health of Ukraine dated August 1, 2011 No. 454 "On approval of the Concept of quality management of medical care in the field of health care in Ukraine for the period up to 2020". Available from: https://zakon.rada.gov.ua/rada/show/v0454282-11. Ukrainian.
І. М. Щербакова // Педагогічні науки: теорія, історія, інноваційні технології. - 2015. - № 1(45). - С. 186-192. http:// repository.sspu.sumy.ua/handle/123456789/1372

15. Оцінка медичної сорери в Україні. Соціологічна група «Рейтинг», 2019. http://ratinggroup.ua/files/ratinggroup/ reg_files/rg_report_healthcare_052019_press.pdf

16. Охорона здоров'я. http://medlib.dp.gov.ua/jirbis2/ images/BOOK_full/dodatok.pdf : довідник кваліфікаційних характеристик професій працівників. - Вип. 78.

9. Order of the Ministry of Health of Ukraine dated September 28, 2012 No. 752 "On the procedure for quality control of medical care". Available from: https://zakon.rada. gov.ua/laws/show/z1996-12. Ukrainian.

10. Order of the Ministry of Health of Ukraine dated August 6, 2013 No. 693 "On the organization of clinical and expert assessment of the quality of medical care". Available from: https://zakon.rada.gov.ua/laws/show/z0285-16. Ukrainian.

11. Order of the Ministry of Health of Ukraine dated September 11, 2013 No. 795 "On monitoring of clinical indicators of quality of medical care". Available from: https:// zakon.rada.gov.ua/laws/show/z1669-13. Ukrainian.

12. West CP, Dyrbye LN, Erwin PJ, Shanafelt TD. Interventions to prevent and reduce physician burnout: a systematic review and meta-analysis. The Lancet. 2016;388(10057): 2272-81. DOI: 10.1016/s01406736(16)31279-x

13. Electronic journal "Management of a health care institution". Available from: https://egolovlikar.mcfr.ua/. Ukrainian.

14. Shherbakova IM. Satisfaction with the professional activity as an indicator of neuroticism of subjects of labour. Pedahohichni nauky: teoriia, istoriia, innovatsiini tekhnolohii. 2015;(45): 186-92. Sumy: SumSPU. Available from: http://repository.sspu.sumy.ua/handle/123456789/1372. Ukrainian.

15. Assessment of the medical sphere in Ukraine. Sociological group "Rating" 2019. Available from: http:// ratinggroup.ua/files/ratinggroup/reg_files/rg_report_ healthcare_052019_press.pdf. Ukrainian.

16. Healthcare. Handbook of qualification characteristics of workers' professions. Available from: http://medlib.dp.gov. ua/jirbis2/images/BOOK_full/dodatok.pdf. Ukrainian.

Отримано 02.08.20 